\title{
Conservation Model for Sustainable Groundwater Utilization in Makassar City
}

\author{
Muhammad Amri Akbar ${ }^{1}$, Soemarno ${ }^{2}$, Harsuko Riniwati ${ }^{3}$, Andi Tamsil ${ }^{4}$ \\ \{amriakbar72@gmail.com¹, smno@ub.ac.id ${ }^{2}$, riniwatisepk@gmail.com³ ${ }^{3}$, andi.tamsil@umi.ac.id ${ }^{4}$ \} \\ Universitas Brawijaya, Indonesia ${ }^{1,2,3}$ \\ Universitas Muslim Indonesia, Indonesia ${ }^{4}$
}

\begin{abstract}
Ground water utilization increases along with population growth and city development. Ground water is one of the sources of water to fulfill daily needs for households, government offices, private sectors, businesses and industries. The research was aimed to formulate a conservation model for sustainable groundwater utilization in Makassar City. This research used primary data and used questionnaire techniques for data collection. The data was analyzed by using the AHP (Analytic Hierarchy Process) analysis and the MPE analysis approach (Experimental Comparison Method). The AHP method is intended to determine the priority of sustainable groundwater management strategies in Makassar City. While the MPE method is intended to determine the best model of sustainable groundwater conservation in Makassar City. The results showed that the main strategy in sustainable groundwater management in Makassar City is to increase PAD based on the environment becomes a top priority (49.20\%). While the MPE analysis showed that the best model for sustainable groundwater conservation efforts in Makassar City is the conservation model for groundwater used with a combination of scenarios/models 1, 2, 3, 4 and 5 where the efforts include; saving groundwater, making infiltration wells, harvesting rainwater and installing water meters.
\end{abstract}

Keywords: Conservation Model, Sustainable, Groundwater, Makassar City.

\section{Introduction}

Groundwater is water that moves in the soil contained in the spaces between the grains of soil that form it in the cracks of rocks. The level of ground water utilization in Makassar City is currently high, where based on data analysis, the average groundwater uptake in Makassar City was $2,997.30 \mathrm{~m}^{3} /$ month. This value was high when compared to the maximum amount (volume) permitted which is an average of $2,164.86 \mathrm{~m}^{3} /$ month. The data showed that the current groundwater utilization rate was $174.51 \%$ or has exceeded the maximum permitted limit. This is also reinforced by the fact according to the Makassar City Regional Environment Agency (BLHD) that there was a decrease in groundwater level of 0-3.25 m/year in one of the districts in Makassar due to uncontrolled use of ground water.

Ground water utilization increases with population growth and the city development. This is because ground water is one source of water to fulfill daily needs, both for households, government offices to businesses, businesses and industries. Ground water is water that contained in layers of soil or rocks below the surface of the land which also has a very important role, especially in maintaining the balance and availability of raw water for domestic and industrial purposes. 
For this reason, a groundwater management model in Makassar City is necessary in order to maintain the quality and quantity of groundwater in Makassar City. The integration of AHP and MPE methods is an approach that can be used to formulate conservation models for sustainable groundwater utilization in Makassar City.

\section{Material and Method}

\subsection{Data Types and Sources}

The primary data were obtained using questionnaires by respondents. Respondents are 6 experts who are considered to understand groundwater management in Makassar City. The number of expert respondents is considered to be sufficiently representative as Hora [1] stated that the number of experts who are adequate and have high precision is as much as 3 to 6 or 7 persons.

\subsection{Data Collecting Method}

Data collection methods in this study used a survey method with a questionnaire technique. Questionnaire approved to obtain answers or opinions from experts (expert judgment) related to the model of land use utilization in Makassar City. According to Arikunto [2] that the questionnaire is a data collection technique by sending or sending a list of questions to be filled in by respondents.

\subsection{Data Analysis Method}

The data analysis method in this research was carried out using the AHP (Analytic Hierarchy Process) analysis approach and the MPE analysis approach (Experimental Comparison Method). The AHP method is intended to determine the priority of sustainable groundwater management strategies in Makassar City. While the MPE method is intended to determine the best model of sustainable groundwater conservation in Makassar City.

AHP method is one of the decision Support System (DSS) analysis tools. AHP can decompose the problem of multi-factor/multi-aspect or complex multi-criteria into a hierarchy/level. According to Saaty [3], hierarchy is defined as a representation of a complex problem in a multi-level structure where the first level is the focus (goal), which is followed by the level of criteria and alternative levels. It was further stated that AHP is a method of decision making involving a number of criteria and alternatives selected based on consideration of all related criteria in the form of a hierarchy. With hierarchy, a complex problem can be broken down into groups which are then arranged in a hierarchy so that the problem will look more structured and systematic. According to Marimin [4] AHP has many advantages in explaining the decision-making process, because it can be described graphically, so that it is easily understood by all parties involved in decision making. The AHP method "pairwise comparison" has the ability to solve problems that are studied multi-object and multi-criteria based on the comparison of preferences of each element in the hierarchy. So, this model is a comprehensive model. The decision maker makes the choice of a simple pair of comparisons, establishing all priorities for alternative sequences. "Pairwise comparison" AHP uses existing data that are qualitative based on perception, experience, intuition so that they are perceived and observed, 
but the completeness of numerical data does not support quantitative modeling [5]. Specifically, AHP advantages include; a) The hierarchical structure as a consequence of the selected criteria to the deepest sub-criteria, b) Calculates validity to the limit of inconcentration tolerance as criteria and alternatives chosen by decision makers, and c) Calculates the durability or resilience of the analysis output decision making sensitivity. While AHP weaknesses include; a) The dependence of the AHP model on its main inputs, the main input is the perception of an expert/expert so that in this case it involves the subjectivity of the expert besides the model also becomes meaningless if the expert gives a wrong assessment, b) the AHP method is only a mathematical method without statistical testing, so there is no confidence limit of the truth of the model formed. The exponential comparison method (MPE) is a method for decision making that quantifies the opinion of a person or more on a certain scale [6]. Rangkuti [7] further states that in principle MPE is a scoring method for available choices, with an exponential calculation, the difference in values between criteria can be distinguished depending on the ability of the person assessing. The Exponential Comparison (MPE) method can reduce the bias that might occur in the analysis. For the resulting score, will illustrate the order of priorities that become large, this causes the order of alternative priority decisions become more real. The exponential comparison method has the advantage of reducing the bias that might occur in the analysis. The score value that describes the order of priorities becomes large (exponential function) This results in a more concrete order of alternative priority decisions. According to Yulianti and Juwita [8], the MPE method is able to determine the priority order of alternative decisions using several criteria. This method is able to reduce the bias that might occur in the analysis. For the resulting score, will illustrate the order of priorities that become large, this causes the order of alternative priority decisions become more real. Besides this method is one method of decision making that quantifies the opinion of someone or more on a certain scale. In principle, it is a scoring method for choices. With exponential calculations, the difference in values between criteria can be distinguished depending on the ability of people who judge Rangkuty [7].

\section{Results and Discussion}

\subsection{Priority Aspects of Groundwater Management}

Criteria for sustainable groundwater management strategies in Makassar City, built on 7 (seven) aspects including; a) policies, b) community relations, c) community empowerment, d) enforcement of rules and sanctions, e) technology and information, f) funding schemes, and g) political ecology. Priority criteria for these aspects based on expert opinion are presented as follows: 


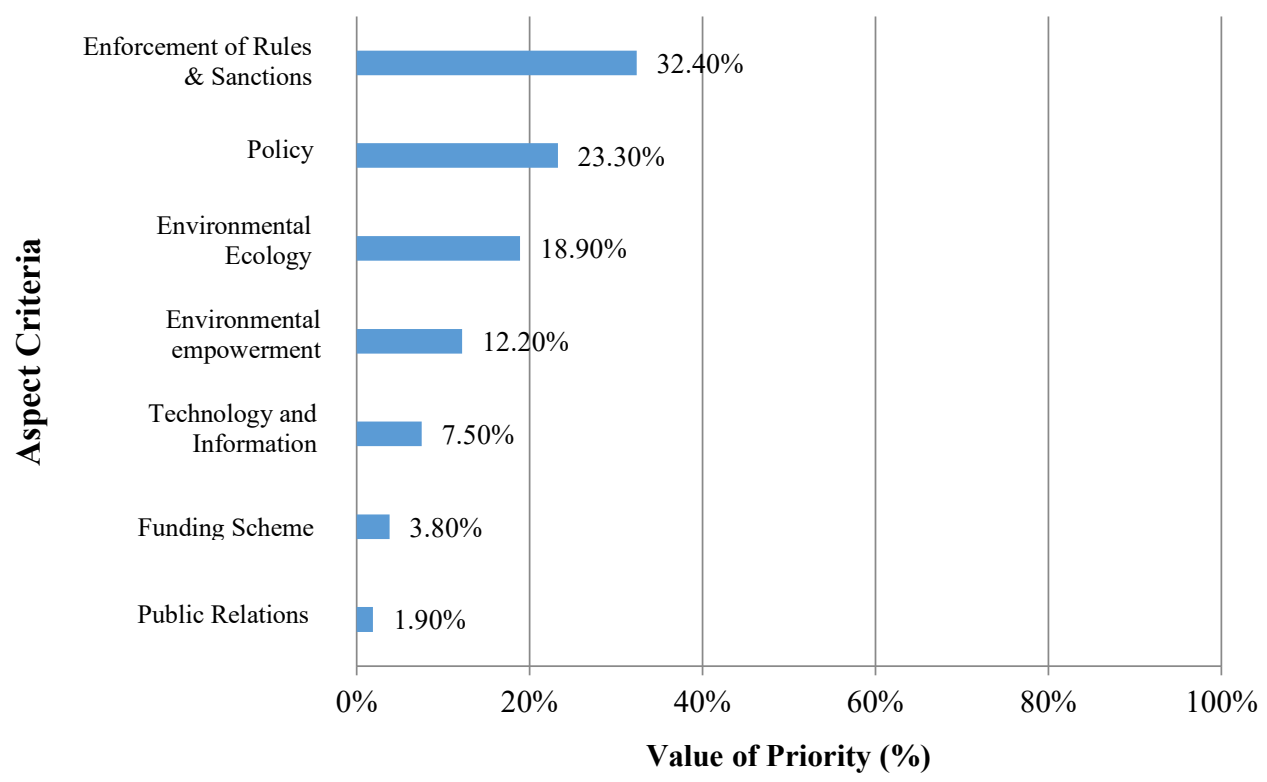

Fig. 1. Priority criteria aspects in sustainable groundwater management strategies in Makassar City.

Enforcement of rules and sanctions is part of law enforcement efforts. Law enforcement has a meaning as a process carried out in upholding the efforts of the law, so that the law with various forms of norms or rules contained therein can function significantly, as a form of guidelines for the behavior of community life and also the life of the state This form of law enforcement itself can also be divided into two forms which are seen from a subjective and objective angle. Law enforcement is also interpreted as an effort by certain law enforcement officials to guarantee and ensure that a rule of law runs as it should. Laws are upheld for the benefit of the community so that a safe and peaceful society is achieved. Imposing strict sanctions in accordance with applicable law to violators of the rules, in this case related to the use of ground water, becomes very important. The aspect of enforcing rules and sanctions is one of the most important aspects at present in all dimensions of social, national and state life.

\subsection{Policy Aspects}

The policy aspect is an important aspect for water management. This is closely related to public policy in the sustainable use of water resources [9]. High population growth rates and rapid urban progress make domestic water needs including ground water in them a primary and vital need. Policy aspects in the strategy of sustainable groundwater management in the City of Makassar include; a) local regulations, b) groundwater management documents, c) licensing (SIPA), d) broad regulation, e) incentives and disincentives, and f) taxes. The following are the results priority aspects for sustainable groundwater management strategies in Makassar City. 


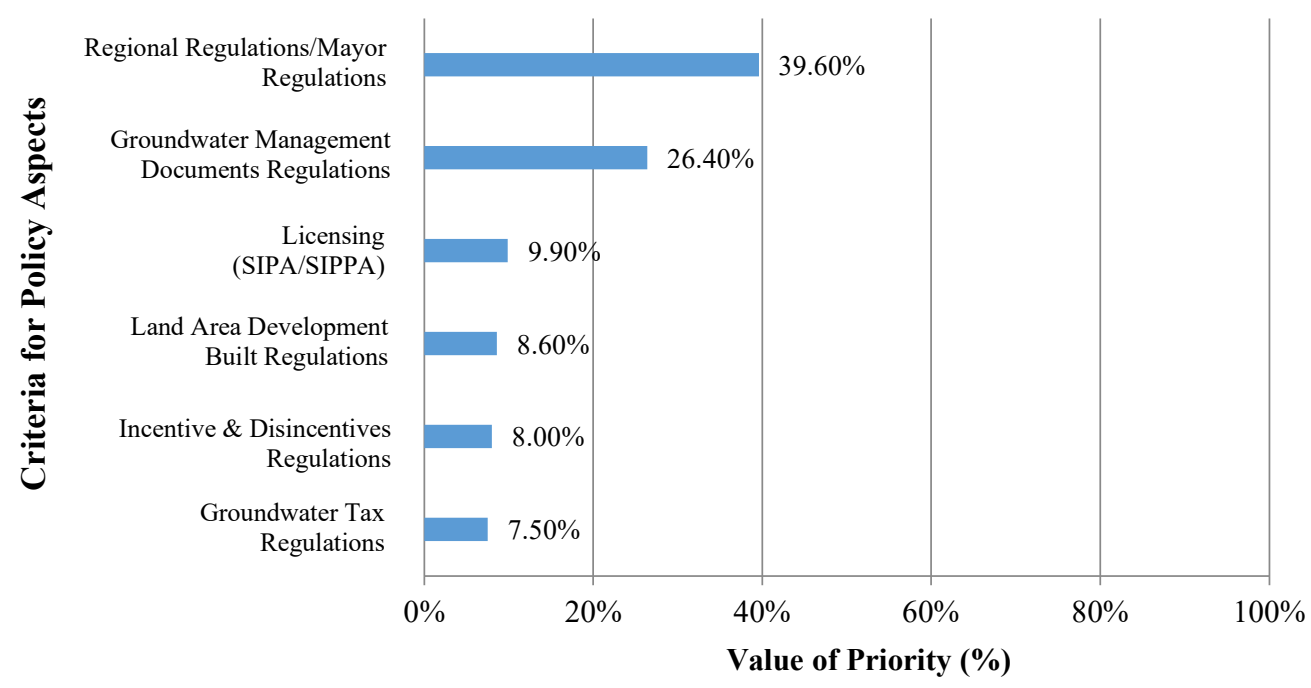

Fig. 2. Priority policy aspects in the strategy of sustainable groundwater management in Makassar City.

Regional regulation (PERDA) is one of the legal products in force in Indonesia. Based on Law Number 12 of 2011 concerning Regulations for the Formation of Legislation (UUP3), the sequence of laws is stated in which the Regional Regulation consists of provincial and district / city regulations. In addition, it is also regulated that the PERDA made must comply with the above or higher laws and regulations. The formation of PERDA is also regulated by Regulation of the Minister of Home Affairs Number 120 of 2018 concerning the Establishment of Regional Legal Products. Related to the management and utilization of groundwater resources in Makassar City, the policies in the form of Regional Regulations is very important. One of the Perda related to groundwater management is Regional Regulation of South Sulawesi Province Number 7 of 2010 concerning Groundwater Management. While local regulations at the Makassar City level related to groundwater management is Number 70 of 2016 concerning Groundwater Conservation through Infiltration Wells and Biopori Infiltration Holes. Given the importance of policies at the regional level. According to Grunig and Hunt [10] that Regional Regulations have several functions, such as; a) as a policy instrument for carrying out regional autonomy as mandated in the 1945 Constitution and Law Number 9 of 2015 concerning Regional Government, b) Is an implementing regulation of the higher laws and regulations and refers to Law Number 12 of 2011 concerning Establishment Laws and Regulations, c) as a reservoir of regional specificity and diversity and channeling the aspirations of the people in the region, remain in the corridor of the Republic of Indonesia based on Pancasila and the 1945 Constitution, and d) as a development tool in improving regional welfare.

\subsection{Public Relations Aspects}

The aspect of community relations is one aspect related to sustainable groundwater management strategies in Makassar City. Community relations is an important aspect of communication. According to Grunig and Hunt [10], public relations are defined as the management of communication between an organization and its publics. The aspects include; a) level of groundwater exploitation, b) level of groundwater conservation, and c) level of 
pressure on groundwater. The results of the priority analysis regarding aspects of public relations as follows:

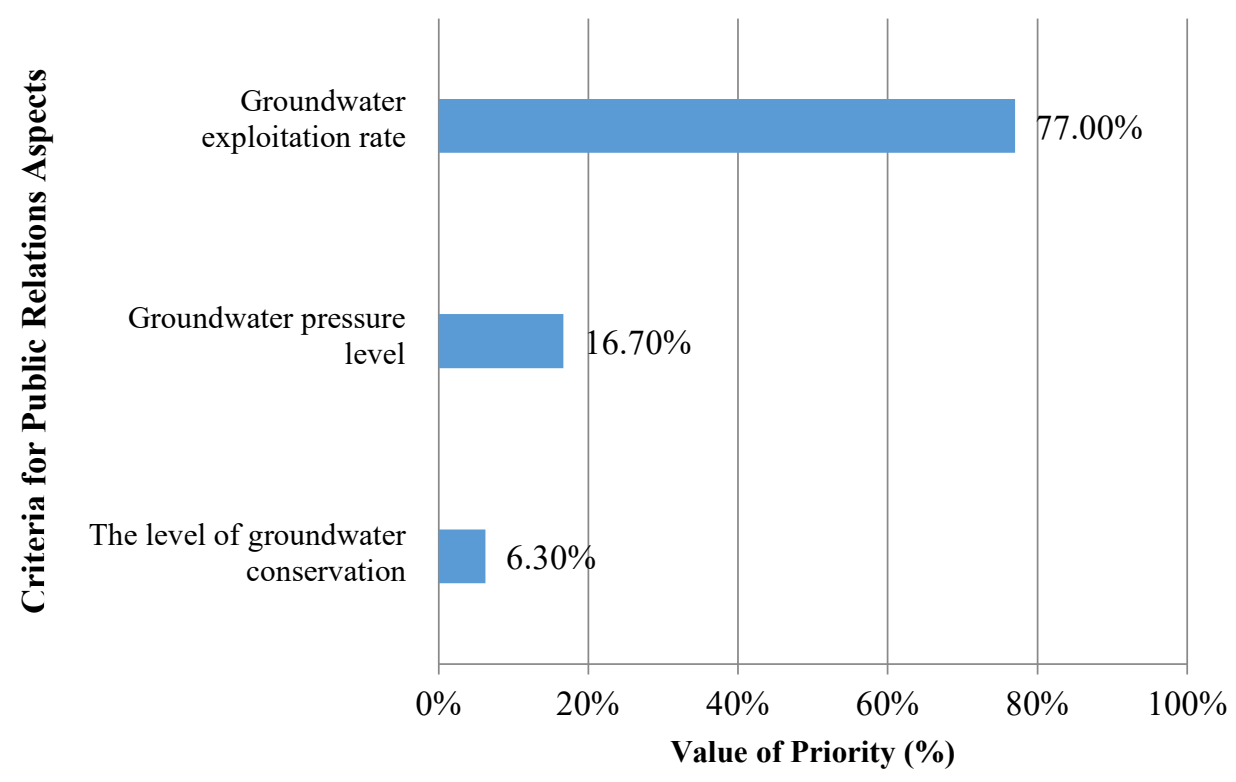

Fig. 3. Priority aspects of community relations in sustainable groundwater management strategies in Makassar City.

A high level of groundwater exploitation will have an impact on the environment both physically and socially. The impact on the physical environment will cause a decrease in the carrying capacity of the environment and even the occurrence of damage such as land subsidence, which can further damage the population building. The high level of groundwater exploitation will cause groundwater extraction to exceed supply or availability, which will cause a deficit in the water balance and result in a continuous decline in ground water without the opportunity for recovery to occur naturally [11]. According to Hendrayana [12], excessive groundwater extraction will have a negative impact on groundwater resources and the environment, among others; land subsidence, sea water intrusion, and subsidence. Seawater intrusion occurs when the hydrostatic balance between fresh groundwater and saltwater in the coastal area is disrupted, where fresh ground water has drastically reduced, then saltwater movement occurs from the sea towards the land.

\subsection{Technology and Information Aspects}

The technological and information aspects are also one of the important aspects in development in general and groundwater management in particular. Likewise, in groundwater management, the role of technology and information is vital. The technological and information aspects of sustainable groundwater management strategies in Makassar City include; a) water meter, b) water saving technology, c) infiltration wells, biopores, d) electronic / print media socialization, e) water recycling, f) groundwater management conservation information system. 


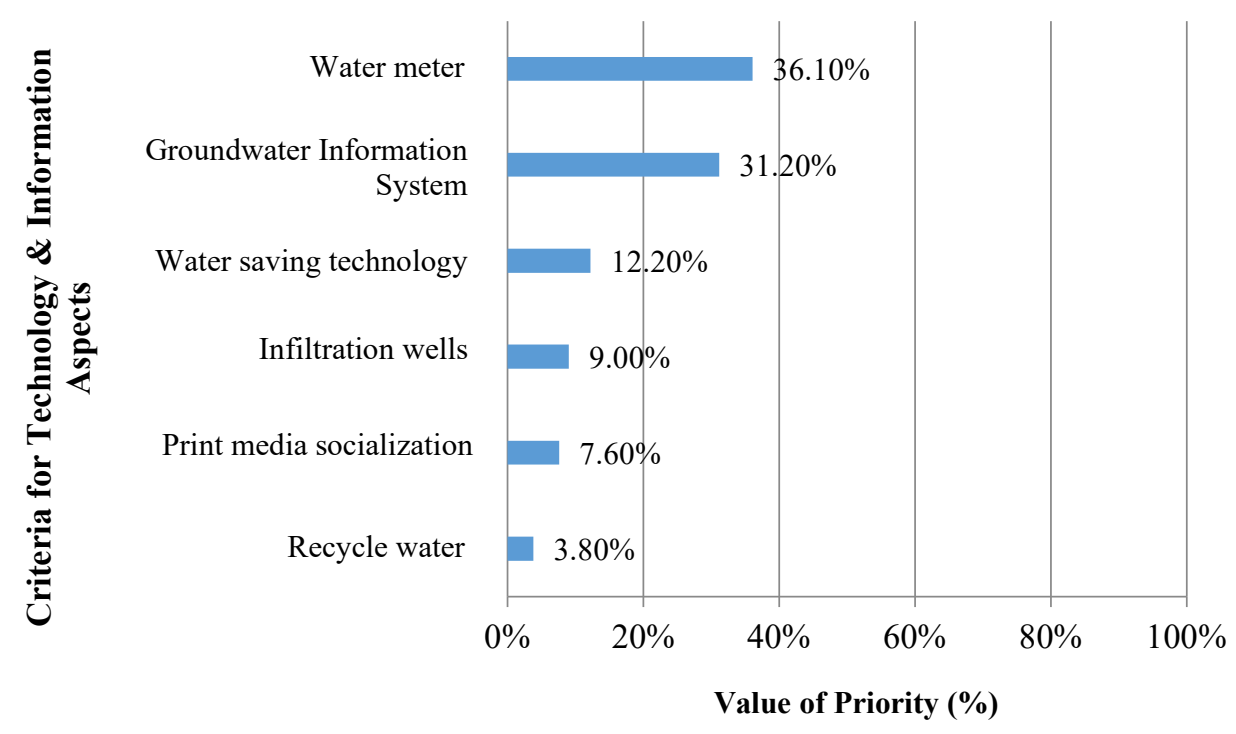

Fig. 4. Priority aspects of technology and information in sustainable groundwater management strategies in Makassar City.

Water meter is a major component in sustainable groundwater conservation efforts. Water meter as a tool to record the volume of water used/taken through a working system of equipment that is equipped with a sensor unit, counter unit, and a unit of measurement indicators that states the volume of water passing through. In addition to the main function as a recorder (recorder) of the volume of water used, the water meter also has an accountability function and encourages water-saving behavior [13]. This is in accordance with the results of research Anggun [14] that the policy that can be carried out in groundwater conservation is the movement to conserve water and increase the production capacity of PDAMs.

\subsection{Aspects of Environmental Empowerment}

The aspect of environmental empowerment is an aspect that is directly related to the environment in this case is the community environment. Environmental empowerment basically aims to increase the potential of the community to be able to improve a better quality of life for all members of the community [15]. The potential of the community to develop self-sufficiency institutions has developed along with the socio-economic progress of the community. In the future it is necessary to further develop the potential of community self-sufficiency, especially community involvement in groundwater conservation efforts that can increase social security, and public awareness in solving various problems related to water needs. Aspects of environmental empowerment in sustainable groundwater management strategies in Makassar City include; a) tree planting, b) ground water use reporting system, c) groundwater quality inspection, d) monitoring wells, and e) rainwater harvesting. The results of the priority analysis related to aspects of environmental empowerment in sustainable groundwater management in Makassar City, are as follows: 


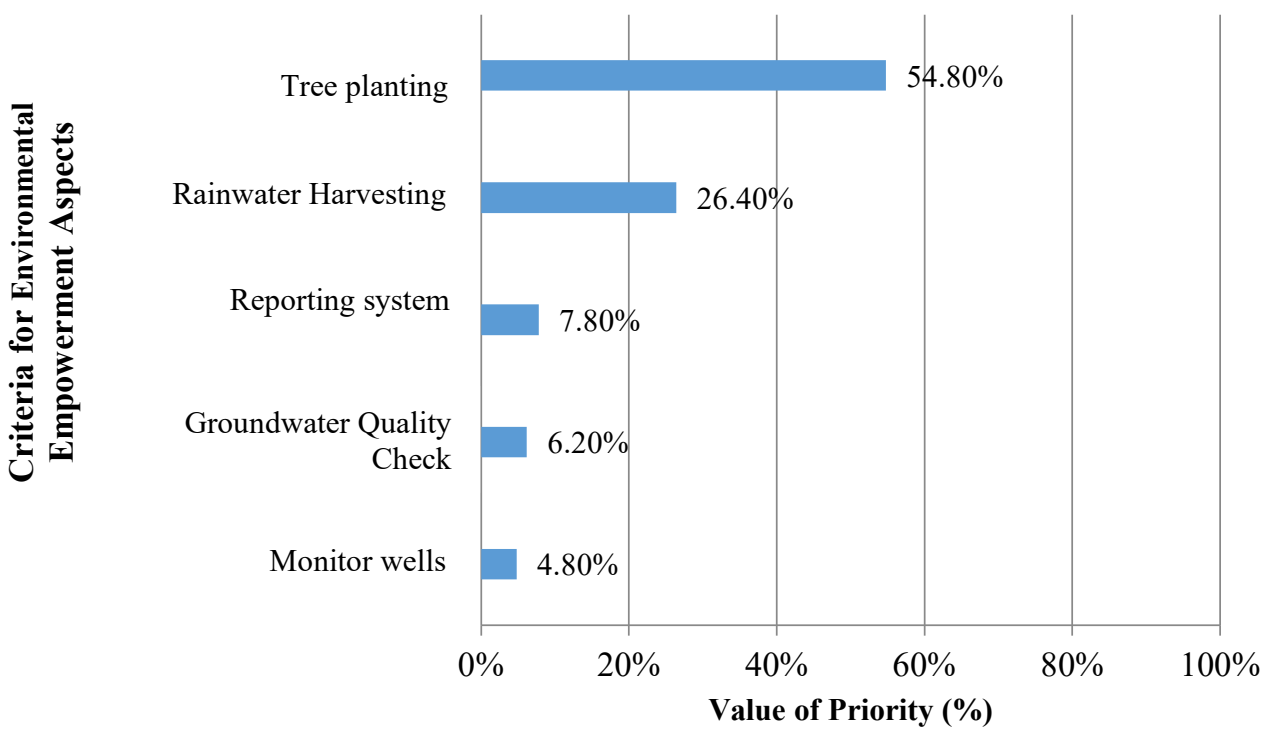

Fig. 5. Priority aspects of environmental empowerment in sustainable groundwater management strategies in Makassar City.

Tree planting activity is an important program in the field of environmental empowerment for groundwater conservation efforts. Trees greatly contribute to maintaining the ground water cycle. When trees are cut down, an area will become arid/dry and nothing will help the soil absorb more water. These conditions cause the loss of soil absorption, it will impact on the reduction in water reserves in the soil, especially in the dry season. This is because the tree that functions as a storage place for groundwater reserves is no longer present, causing a decrease in water resources. The smaller the number of trees in an area / area, it can be ascertained that the ground water content in the region is also small.

\subsection{The Aspect of Rule Enforcement and Sanctions}

Policy enforcement and sanctions are part of law enforcement. It is related to the rules and sanctions in the use of ground water in Makassar City, which is very important considering that ground water in Makassar City is one of the water sources for meeting basic needs and the needs of industry / business. On the other hand, excessive extraction/use of ground water can damage the environment and groundwater itself, both in quality and quantity. Uncontrolled uptake of ground water can cause land subsidence and sea water/salt intrusion into the land area. The priority aspects of enforcement and sanctions include sub aspects; a) periodic monitoring, b) issuance of fines, revocation of permits and closure of wells, c) review of groundwater management plans, d) routine supervision, e) inspection of reports, and f) observations, painting and recording. Following are the results of the analysis of the priority aspects of enforcement and sanctions. 


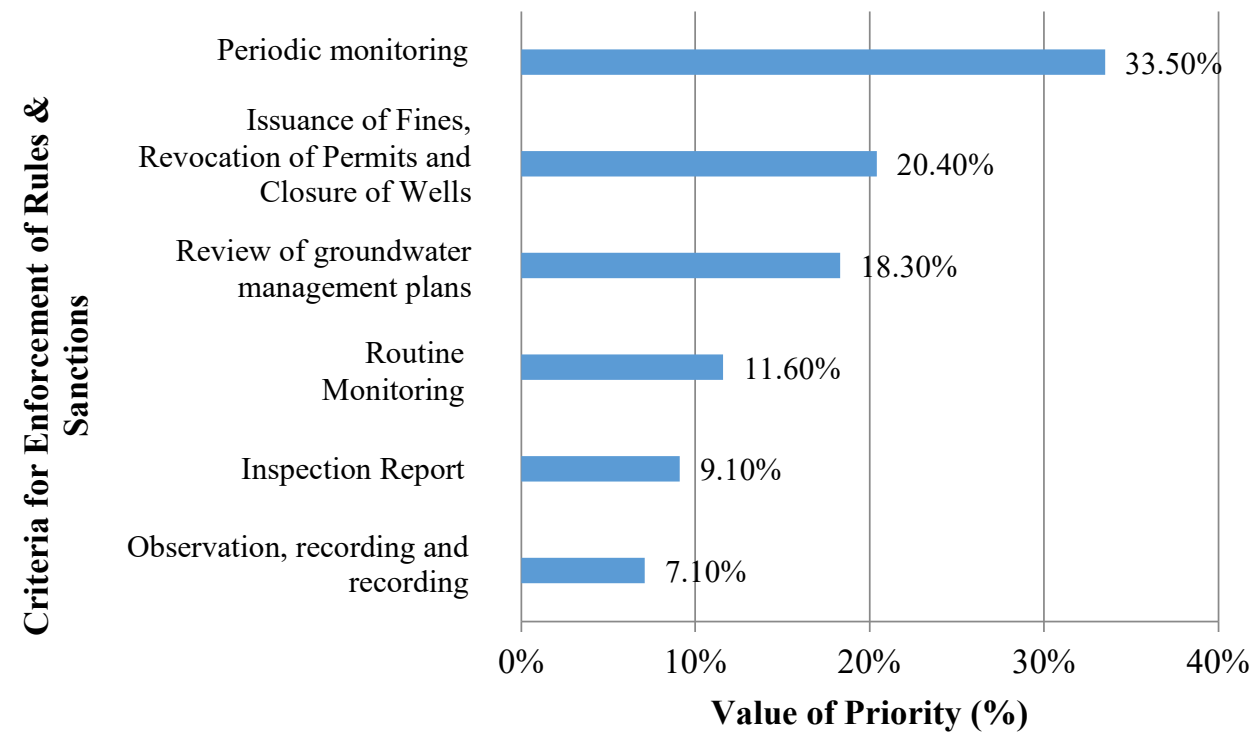

Fig. 6. Priority aspects of rule enforcement and sanctions in strategic planning.

Periodic monitoring is a top priority related to the enforcement of sanctions in the effort to manage sustainable groundwater in Makassar City. Periodic monitoring becomes very important, given the relatively massive groundwater utilization activities in Makassar City, and based on the needs analysis results it is known that the current condition of groundwater utilization has exceeded the maximum permitted limit which has reached $174.51 \%$. The conditions illustrate how massive the level of groundwater uptake is in Makassar City. On the other hand, the results of an analysis of policy assessments related to groundwater management in Makassar City also showed that monitoring and evaluation activities were classified as poor $(37.50 \%)$ or less than $50 \%$. Periodic monitoring activities can provide more complete and valid data as a basis for better policy making. This is as Dunn [15], suggested that monitoring activities have functions, such as; obedience (compliance), examination (auditing), reports (accounting), and explanation.

\subsection{Funding Scheme Aspects}

Funding scheme is intended as a form or source of funding in this case related to groundwater management activities in Makassar City. Priority aspects of the funding scheme include sub aspects; a) APBD contributions, b) Cost Sharing, c) Private Contributions (CSR), d) Self-Help Efforts, and e) State Budget Contribution. Following are the results of the priority analysis of aspects of the funding scheme related to sustainable groundwater management in Makassar City. 


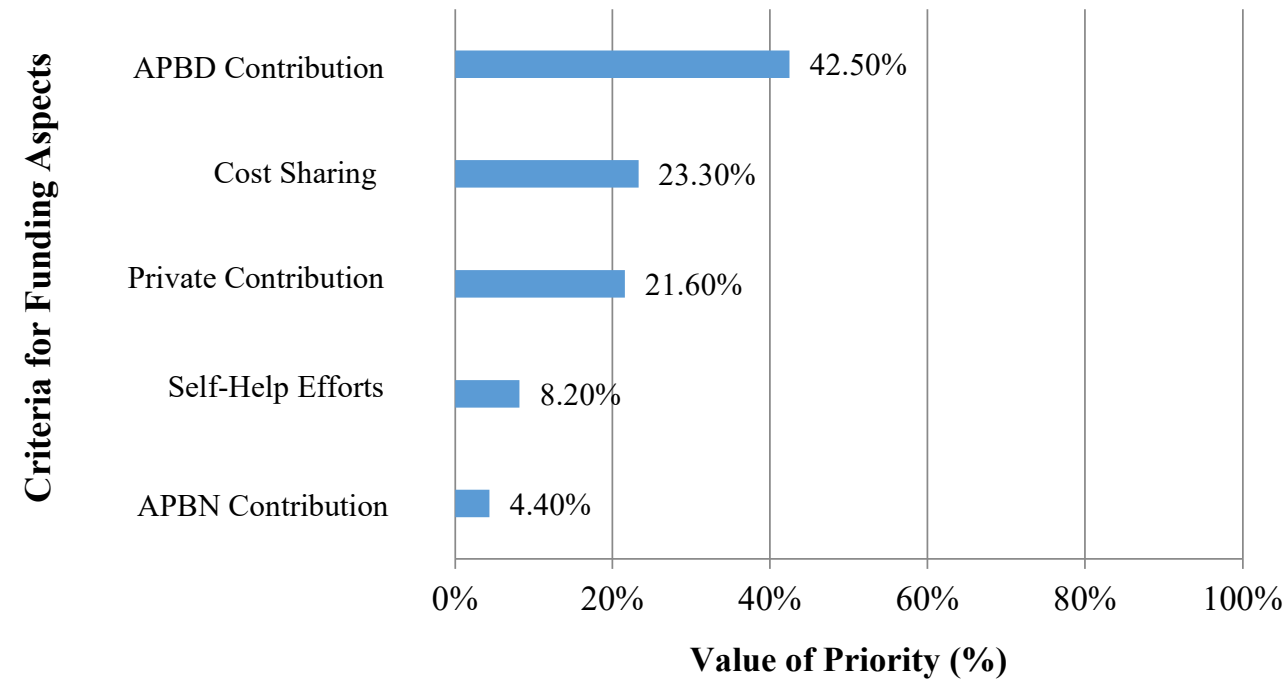

Fig. 7. Priority aspects of funding in sustainable groundwater management strategies in Makassar City.

APBD contribution is a top priority related to funding schemes in sustainable groundwater management in Makassar City. Based on the Minister of Home Affairs Regulation No. 13 of 2006 concerning the Guidelines for Regional Financial Management, it is stated that the Regional Budget (APBD) is a regional annual financial plan that is discussed and agreed jointly by the Regional Government with the Regional Representative Council (DPRD), and determined through Local regulation.

\subsection{Political Ecology Aspects}

The political ecology aspect is one of the important aspects in the development of sustainable development policies. The priority aspects of political ecology in sustainable groundwater management in Makassar City include sub aspects; a) Commitment of City Government/DPRD to maintain groundwater management, b) Regional Planning and Budgeting for Groundwater Management, c) Agenda for political campaigns, d) Strength of NGOs, and e) Effectiveness of DAS forums. Following are the priority aspects of political ecology in sustainable groundwater management in Makassar City. 


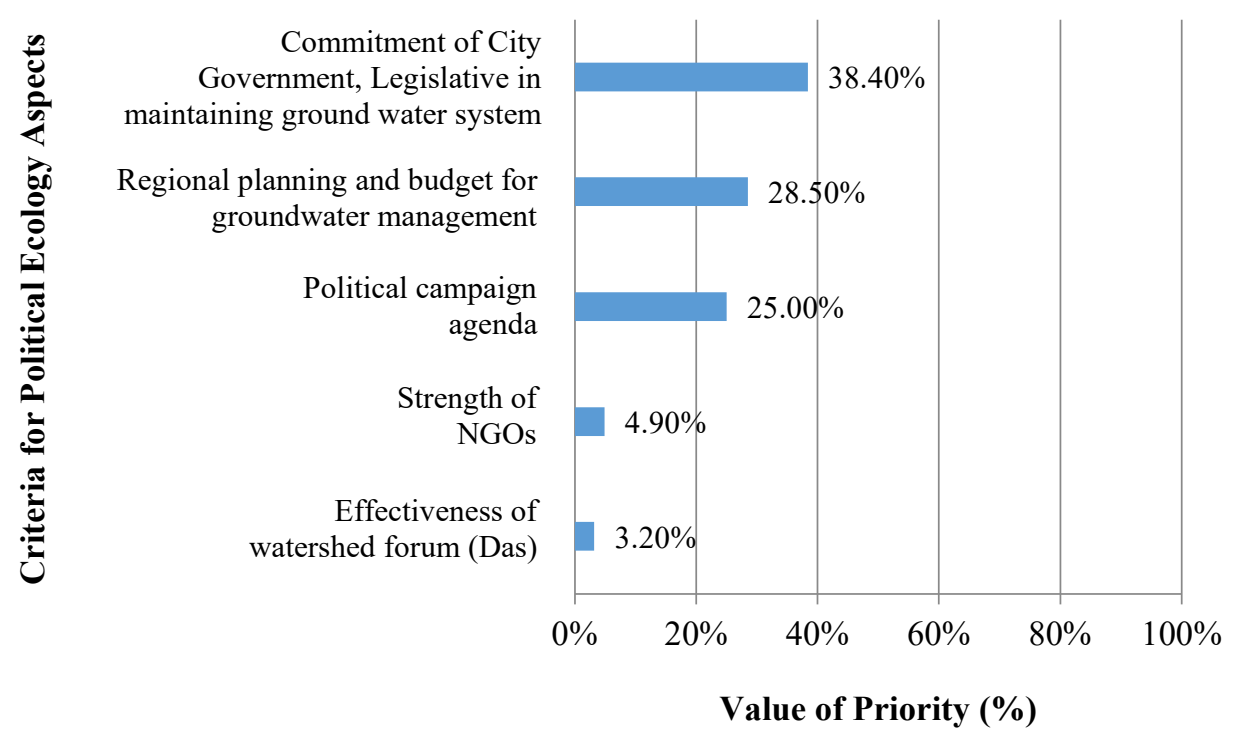

Fig. 8. Priority aspects of political ecology in the strategy of sustainable groundwater management in Makassar City.

The commitment of the City Government/DPRD to maintain groundwater management in Makassar City is very important in the view of sustainable groundwater management policies. According to Steers and Porter [16], commitment is a condition in which an individual becomes bound by his actions so that it will cause beliefs that support his activities and involvement. Commitment in this matter is interpreted as a manifestation of the political will of the Makassar City Government/DPRD to conduct groundwater management in a sustainable manner. Political will is interpreted as the political will of policy makers.

\subsection{Alternative Priority Strategies}

Alternative strategies for sustainable groundwater management in Makassar City, include; a) preservation of ground water, b) environmental preservation and c) increase in regional-based own-source revenue (PAD). Below are the results of alternative priorities for sustainable groundwater management strategies in Makassar City. 


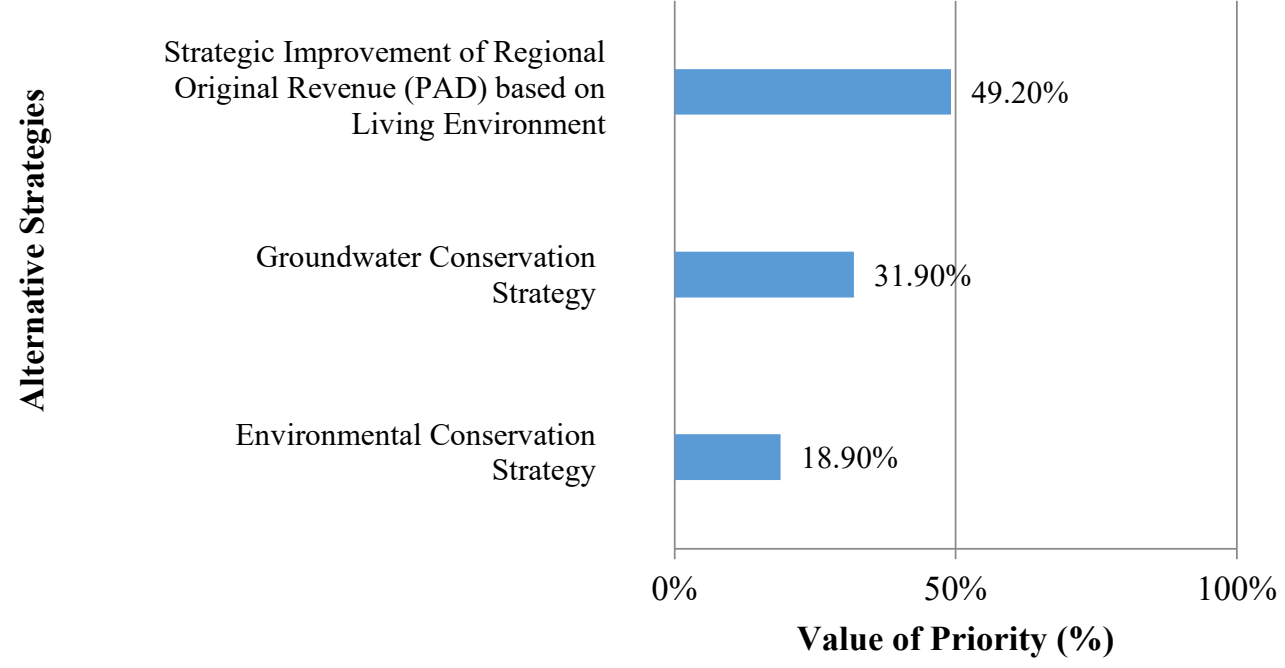

Fig. 9. Priority alternative strategies for sustainable groundwater management in Makassar City.

The strategy is to increase PAD based on the environment that must be applied to manage sustainable groundwater in Makassar City. This strategy will provide a win-win solution. On the one hand, it is aimed to increase PAD (regional revenue). On the other hand, the funds obtained can be allocated in part for groundwater conservation efforts. In economic theory, this condition is called the ecological-economic approach.

\subsection{Conservation Model for Groundwater Utilization}

Referring to the results of the process hierarchy analysis (AHP), then various models of conservation of sustainable groundwater in Makassar are formulated. The formulation of the groundwater conservation model is a form of groundwater problem solving scenario in Makassar City. According to Dunn [17] policy formulation (policy formulation) is the development and synthesis of alternative solutions to problem solving. The approach used in policy formulation (sustainable groundwater conservation models in Makassar City) is the Rational-Comprehensive Model. According to Hoogerwerf in Islamy [18] that the rationalcomprehensive (synoptic) policy analysis model is one analysis of the results or impacts that have the purpose that the process of formulating public policy will produce good results or impacts if it is based on a rational thought process that is supported by data or complete information (comprehensive). Thus, the formulation of policies using complete data and is expected to be valid, so that the formulation provides good policy results. The following is a formulation of policies related to groundwater conservation efforts in a sustainable manner in Makassar City. Determination or selection of models was carried out using the MPE (Experimental Comparison Method) approach, which is integrated with the AHP (Analytical Hierarchy Process) output with expert judgment (expert judgemnet). The MPE analysis results obtained an alternative value of each sustainable groundwater conservation model in Makassar City, as follows: 


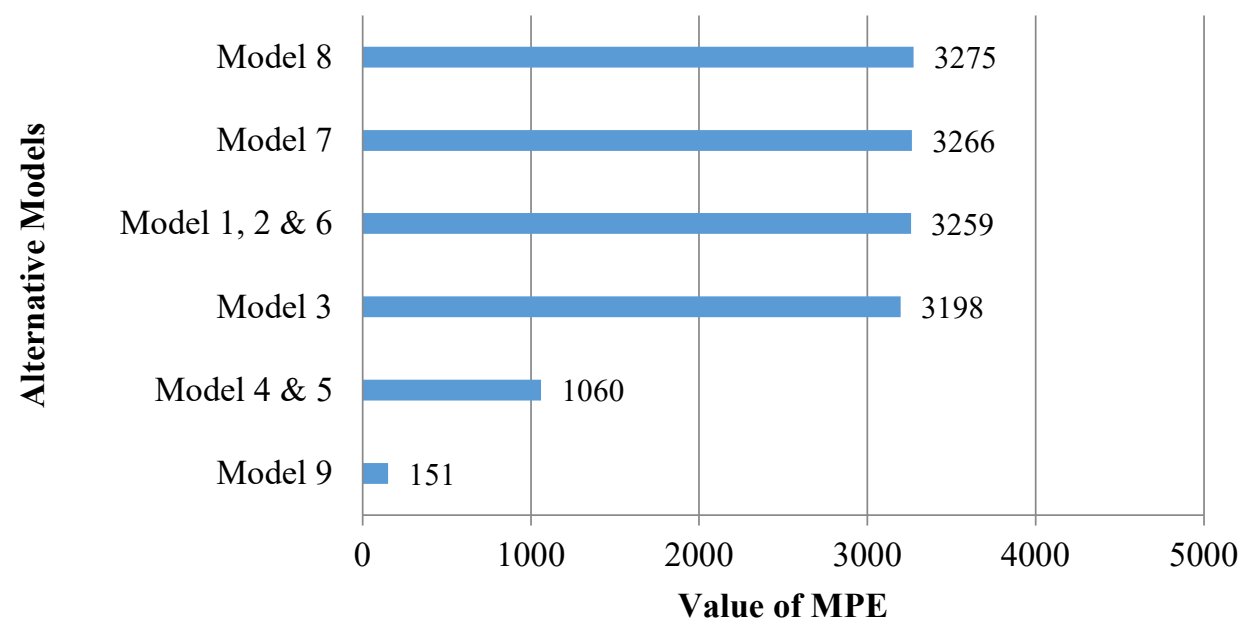

Fig. 10. Alternative values of the Sustainable Groundwater Conservation Model in Makassar City.

Based on the results of an alternative assessment using the MPE method in the picture above, it was found that the conservation model for groundwater utilization with a combination of scenarios/models 1, 2, 3, 4 and 5 is the first alternative to sustain groundwater conservation in Makassar City. While the second alternative is the combination of scenarios/models 1,2, and 3 . Alternative model 8 is a combination of actions from 5 models including a) saving ground water, b) making infiltration wells, c) harvesting rainwater and d) installing water meters, which are required of the five groups of groundwater users in Makassar City.

\section{Conclusion}

The main alternative related to sustainable groundwater management strategies in Makassar City is the strategy to increase PAD based on the environment is a top priority $(49.20 \%)$. While the best model related to sustainable groundwater conservation efforts in Makassar City is the conservation model of groundwater utilization with a combination of scenarios/models 1, 2, 3, 4 and 5 . Followed by the conservation model for groundwater utilization by combining scenarios/models 1,2 , and 3 .

\subsection{Acknowledgements}

Special thanks to local government especially BAPPPEDA of Makassar City.

\section{References}

[1] S. C. Hora, "Probability judgments for continuous quantities: Linear combinations and calibration," Manage. Sci., vol. 50, no. 5, pp. 597-604, 2004.

[2] S. Arikunto, "Research procedure a practical approach," Jakarta PT Rineka Reserv., 2010. 
[3] T. L. Saaty, "Decision making with the analytic hierarchy process," Int. J. Serv. Sci., vol. 1, no. 1, pp. 83-98, 2008.

[4] Marimin, Decision Making Techniques and Applications of Multiple Criteria. Bogor: IPB Press, 2004.

[5] J. P. Saxena and P. Vrat, "Hierarchy and classification of program plan elements using interpretive structural modeling: a case study of energy conservation in the Indian cement industry," Syst. Pract., vol. 5, no. 6, pp. 651-670, 1992.

[6] Marimin, Concept and Application of Decision Support Systems. Yogyakarta: Andi Publisher, 2007.

[7] A. H. Rangkuti, "Teknik Pengambilan Keputusan Multi Kriteria Menggunakan Metode Bayes, Mpe, Cpi Dan Ahp," ComTech Comput. Math. Eng. Appl., vol. 2, no. 1, pp. 229-238, 2011.

[8] E. Yulianti and F. Juwita, "Sistem Pendukung Keputusan Pemilihan Tempat Kuliner Di Kota Padang Menggunakan Metode Perbandingan Eksponensial (Mpe),”J. TeknoIf, vol. 4, no. 2, 2016.

[9] C. Seftyono, A. B. Setiawan, and E. Arditama, "Water and Society: Contextualization of Science in Politics and Public Policy," JKAP (Jurnal Kebijak. dan Adm. Publik), vol. 21, no. 2, pp. 144 154, 2017.

[10] J. E. Grunig and T. T. Hunt, Managing public relations. Holt, Rinehart and Winston, 1984.

[11] P. Pratiknyo, "Aquifer System and Groundwater Reserves in South Sulawesi Province," MTG Sci. J., vol. 1, no. 1, 2008.

[12] H. Hendrayana, "Penetapan Program Pengelolaan Airtanah Di Cekungan Airtanah YogyakartaSleman," Lap. Penelit., 2011.

[13] R. K. Linsley, J. B. Franzini, D. L. Freyberg, and G. Tchobanoglous, "Water resource engineering," Hand Book, Third Ed. McGraw-Hill, INC, 1979.

[14] Anggun, "Groundwater Conservation Using a Dynamic System Method (Case Study: Makassar City, South Sulawesi Province)," Postgraduate of Hasanuddin University, 2017.

[15] Khoriddin, Community Development. Yogyakarta: Liberty Thing, 1992.

[16] R. M. Steers and L. W. Porter, Motivation and work behavior. McGraw-Hill, 1983.

[17] W. N. Dunn, Pengantar analisis kebijakan publik. Gadjah Mada University Press, 2000.

[18] I. Islamy, "Dasar-Dasar Administrasi Publik dan Manajemen Publik," Malang Univ. Brawijaya, 2003. 